\title{
ISOLASI DAN KARAKTERISTIK JAMUR PELAPUK DARI BATANG DAN TANDAN KOSONG KELAPA SAWIT
}

\author{
(Isolation and Characteristic of Fungus Rot of Stem and Empty \\ Fruit Bunches of Oil Palm)
}

\author{
Muh. Yusuf Idris, Sukriming Sapareng*, Irwan Halid \\ Faculty of Agriculture, Andi Djemma Palopo University, South Sulawesi, Indonesia \\ *Corresponding author : email : miming.mlgke@gmail.com
}

\begin{abstract}
Rot fungus has the ability to degrade stem and empty fruit bunches oil palm for producing an enzyme that can break down cellulose, hemicellulose, and lignin. Fungal isolates obtained from stem oil palm which had rotted and empty fruit bunches oil palm. Isolates were observed macroscopically and microscopically. Macroscopic observation includes growth speed, colony color, elevation and the edge of the colony. Microscopic observations include the shape of fungal spores and conidiophores. The research found rot fungi are 32 isolates comprising 17 isolates from oil palm stem decaying and 15 isolates from empty fruit bunches oil palm. Trichoderma isolates sp3 colony having a diameter of highs, lows and Absidia sp isolates were grown on PDA.
\end{abstract}

Keywords : Isolation, characteristic, fungus, empty fruit bunches, oil palm

\section{PENDAHULUAN}

Batang sawit mempunyai masa produktif secara umum lebih kurang 25 tahun, setelah itu tanaman sawit harus diremajakan. Dari peremajaan akan dihasilkan sejumlah biomassa. Mengembalikan biomassa ke areal perkebunan membutuhkan waktu yang lama. Biomassa yang tetap berada pada areal perkebunan setelah peremajaan dapat menjadi sumber hara bagi tanaman baru. Agar unsur hara dapat tersedia bagi tanaman, maka batang sawit yang sudah ditebang perlu terdekomposisi terlebih dahulu. Demikian juga hal dengan tandan kosong kelapa sawit (TKKS), produksi TKKS diperkirakan mencapai 30 juta ton per tahun (Sajab et al., 2013). Namun, limbah ini belum dimanfaatkan secara baik oleh sebagian besar pabrik kelapa sawit di Indonesia. Dalam waktu yang relatif panjang, keberadaan limbah ini mendatangkan masalah pencemaran. Pemanfaatan limbah ini diharapkan akan mengurangi masalah serta mendatangkan keuntungan jika dikelola menjadi barang yang bernilai dengan menggunakan fungi.

Fungi mempunyai kemampuan untuk mendegradasi batang dan TKKS karena menghasilkan enzim yang dapat menguraikan selulosa, hemiselulosa, dan lignin. Batang sawit merupakan bahan berlignoselulosa seperti kayu, kandungan kimia batang sawit adalah selulosa 
$54,38 \%$,; lignin $23,95 \%$; abu 2,02\%, dan unsur-unsur lainnya. Dengan pendekatan bahwa batang sawit bahan berlignoselulosa maka dekomposisi sawit tidak jauh berbeda dengan dekomposisi kayu (Bakar, 2003). Berdasarkan hal tersebut pemanfaatan fungi pelapuk kayu yang sudah teridentifikasi memungkinkan untuk digunakan dalam mempercepat proses degradasi pohon sawit.

Kemampuan jamur dalam mendegradasi lignin disebabkan adanya enzim ekstrseluler yang disekresikan oleh hifa jamur (Masai et al., 2007), seperti mempercepat proses pengomposan oleh Trichoderma (Sapareng et al., 2017). Eaton dan Hale (1993) menyebutkan berbagai enzim yang berperan dalam proses degradasi lignin yang disekresikan oleh jamur pelapuk putih meliputi lignin peroksidase (LiP), mangan peroksidase $(\mathrm{MnP})$, lakase, demetoksilase, $\mathrm{H}_{2} \mathrm{O}_{2-}$ generating enzyme, dan enzim pendegradasi monomer seperti selobiosa dehidrogenase, asam vanilat hidrolase, dan trihidroksi benzendioksigenase. Namun enzim ligninolitik utama yang dihasilkan jamur adalah lignin peroksidase (LiP), mangan peroksidase (MnP), dan laktase.

\section{BAHAN DAN METODE}

\section{Isolasi Jamur Endofit.}

Batang kelapa sawit dan TKKS dicuci dengan air suling, dipotong menjadi 1-2 cm. Permukaan disterilkan dengan tiga kali perendaman, pertama dalam etanol $70 \%$ selama 1 menit, kedua dalam larutan $\mathrm{NaOCl} 5,25 \%$ selama 5 menit dan yang terakhir, dalam larutan etanol $70 \%$ selama 0,5 menit. Komposisi media adalah $15 \mathrm{~g}$ agar, $15 \mathrm{~g}$ bubuk kering dari batang kelapa sawit, 0,2 g kloramfenikol, dan hingga 1 liter air suling. Inkubasi dilakukan pada suhu kamar $\left(28^{\circ} \mathrm{C}\right)$ selama 1-3 minggu tergantung pada tingkat pertumbuhan jamur. Koloni jamur kemudian dipindahkan ke media baru dengan komposisi 15 g agar, 15 g Ekstrak Malt, dan hingga $1 \mathrm{~L}$ air suling, dan disesuaikan dengan $\mathrm{pH} 7,4$ hingga 7,8.

\section{Peremajaan Isolat.}

Sebanyak 1 ose isolat cendawan dari kultur koleksi dipindahkan ke dalam media PDA (potatoes dextrose agar) baru. Peremajaan ini dilakukan secara steril dalam kabinet laminar air flow. Isolat yang telah dipindahkan kemudian dibiarkan tumbuh selama 3-7 hari pada suhu ruang. 
Pengamatan Morfologi Jamur.

Morfologi jamur diamati secara makroskopik dan mikroskopik. Pengamatan secara makroskopis mengacu pada Shahid et al. (2013) yang meliputi kecepatan pertumbuhan, warna koloni, elevasi dan bentuk tepian koloni. rakyat di Desa Pattimang Kecamatan Pengamatan mikroskopis diawali dengan Malangke Kabupaten Luwu Utara meneteskan larutan $\mathrm{KOH}$ di atas kaca Propinsi Sulawesi Selatan, dan sisanya 17 preparat lalu isolat dicampur sebanyak isolat hasil isolasi dari tandan kosong satu ose (Gams dan Bissett, 1998). kelapa sawit pada Pabrik Kelapa Sawit Preparat ditutup dengan cover glass lalu Luwu unit 1, Desa Lagego Kecamatan diamati bentuk spora dan konidiofornya Burau, Kabupaten Luwu Timur Propinsi menggunakan mikroskop cahaya.
Hasil isolasi dan pemurnian isolat cendawan pelapuk yang berasal dari dua lokasi yaitu 32 isolat cendawan pelapuk, yang terdiri dari 15 isolat hasil isolasi dari batang kelapa sawit yang sudah mengalami pelapukan pada perkebunan Sulawesi Selatan (Tabel 1).

\section{HASIL DAN PEMBAHASAN}

\section{Morfologi Jamur}

Tabel 1. Hasil isolasi dan pemurniaan isolat cendawan pelapuk asal TKKS dan batang kelapa sawit

\begin{tabular}{cllc}
\hline \hline Isolat & \multicolumn{1}{c}{ Sumber } & \multicolumn{1}{c}{ Lokasi } & Jumlah \\
\hline \hline BT & Batang Tanaman Kelapa Sawit & $\begin{array}{l}\text { Pekebunan Kelapa Sawit Desa } \\
\text { Pattimang } \\
\text { TK }\end{array}$ & Pang Sudah Melapuk \\
& Tandan Kosong Kelapa Sawit & PKS Desa Lagego & 15 \\
\multicolumn{2}{c}{ Total } & 17 \\
\hline \hline
\end{tabular}

Ket $:$ BT $=$ Batang Tanaman Kelapa Sawit, TK = Tandan Kosong Kelapa Sawit

Isolat yang telah dimurnikan (32 pertumbuhannya sangat cepat, memiliki isolat) dilakukan pengukuran kecepatan miselium aerial, awalnya berwarna putih, pertumbuhan pada media PDA dan dipilih kemudian berubah menjadi putih 15 isolat cendawan pelapuk terbaik. kehijauan atau kuning kehijauan Pengamatan menggunakan mikroskop (Trichoderma sp. 1; Trichoderma sp. 3), cayaha menunjukkan bahwa isolat dan hijau tua dan menggumpal terbanyak pada TKKS yaitu isolat genus (Trichoderma sp. 2). Struktur hifa, Trichoderma (isolat TK9, TK10, TK14), bersekat, konidiofor bercabang dan 
terdapat fialid di setiap percabangannya. hari menandakan tingkat pertumbuhan Percabangan fialid ada yang rapat ada isolat yang relatif cepat. Jumlah spora yang renggang. Kumpulan konidia antar masing-masing isolat kurang lebih melekat di ujung fialid, konidia berbentuk sama menunjukkan kecepatan tumbuh bulat atau oval dan hialin (Gambar 1). yang seragam.

Banyaknya spora pada isolat berusia tiga

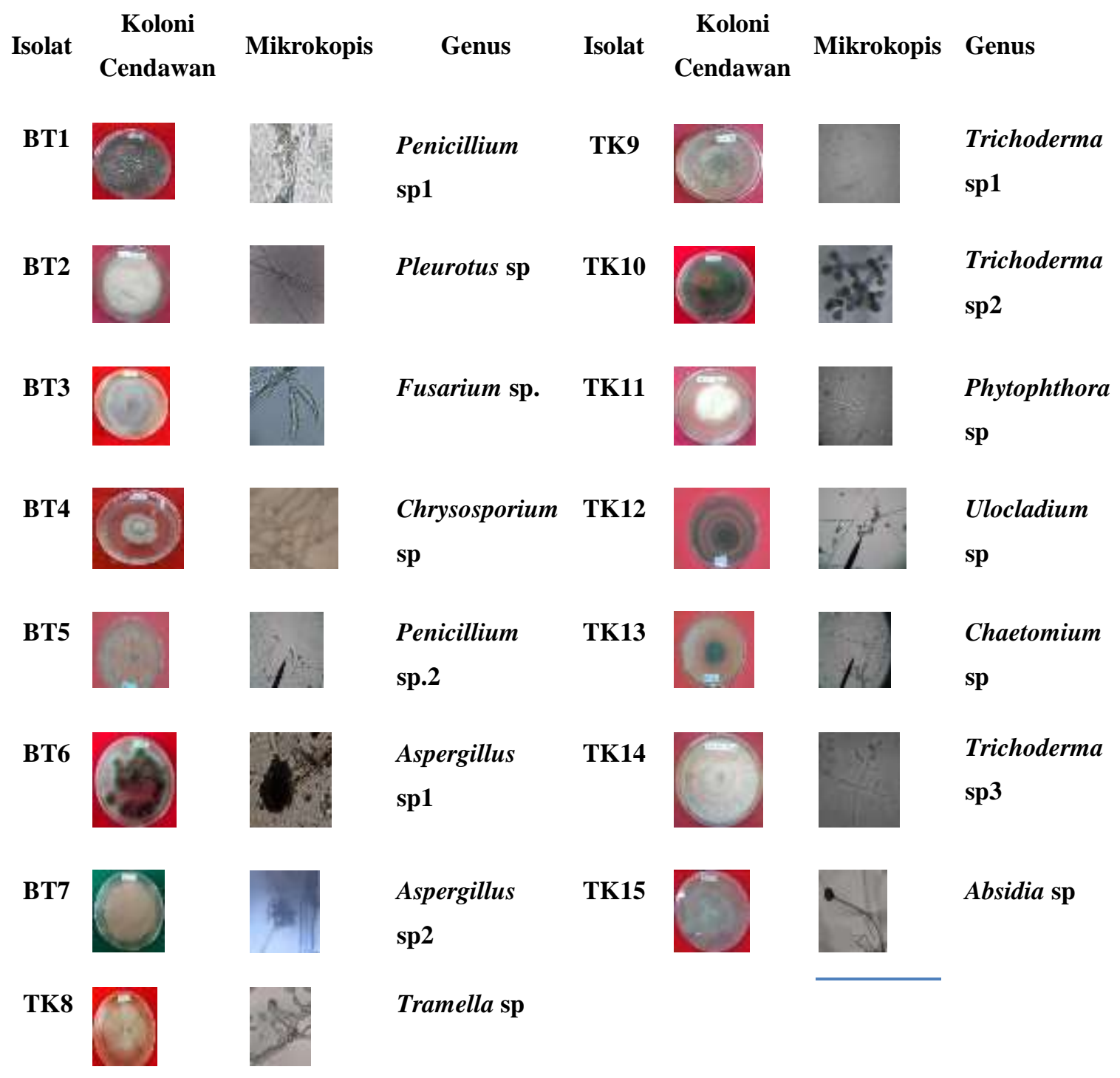

Gambar 1. Hasil isolasi cendawan pelapuk asal TKKS dan batang kelapa sawit 
Semua isolat dengan pertumbuhan tinggi menunjukkan percabangan konidiofor yang cukup tinggi dan berbentuk seperti piramida. Hal tersebut sesuai dengan hasil morfologi pertama yang diklasifikasikan oleh Rifai (1969) bahwa percabangan konidiofor Trichoderma sp sangat tinggi dengan pola menyerupai piramida atau konikal. Spora yang teramati berwarna hijau hingga keabuan berbentuk bulat dan menyebar di sekitar konidiofor. Athul dan Jisha (2013) juga menyatakan bahwa konidia Trichoderma sp. berbentuk bulat hingga elips, uniselular, dan dihasilkan dari konidiofor yang bercabang seperti susunan piramida. Hasil penelitian sebelumnya (Khang et al. 2013) menunjukkan Trichoderma sp. memiliki permukaan yang rata dengan struktur lembut seperti wol, spora hijau yang menyebar, dan pigmen kuning-hijau yang berdifusi ke dalam media tumbuh. Hal ini sesuai dengan penelitian yang telah dilakukan sebelumnya oleh Druzhinina et al. (2006) bahwa Trichoderma asperellum merupakan isolat terbanyak yang ditemukan pada daerah tropikal.Hoyos-Carvajal et al. (2009) juga menyatakan bahwa spesies umum yang ditemukan pada daerah neotropikal adalah
Trichoderma asperellum diikuti dengan Trichoderma harzianum.

\section{Karakteristik Fungi}

Pertumbuhan koloni isolat cendawan pelapuk pada hari ke-7 masa inkubasi mencapai 7-8 $\mathrm{cm}$ pada media PDA. Pertumbuhan tertinggi dicapai oleh 10 isolat yaitu BT1, BT2, BT3, BT4, BT5, BT7, TK8, TK9, TK10, dan TK4, sedangkan pertumbuhan koloni terendah dicapai 5 isolat yaitu BT6, TK11, TK12, TK13, dan TK15. Kecepatan tumbuh hifa berhubungan erat dengan karakter yang khas dari masing-masing isolat. Selain itu, juga dipengaruhi oleh genetik, kandungan media tumbuh, lingkungan tumbuh, suhu dan $\mathrm{pH}$ media (Tabel 2).

Morfologi makroskopik 15 isolat secara umum memiliki permukaan rata menyerupai wol dengan tepian berbentuk regular. Hampir semua isolat berwarna putih, dan hanya dua isolat yang berwarna hijau. Warna yang semakin hijau menandakan jumlah spora yang semakin banyak. Keragaman cendawan dipengaruhi oleh media tumbuhnya. Kandungan bahan organik sangat mempengaruhi populasi mikroba karena bahan organik digunakan sebagai penyusun tubuh dan sumber energi bagi 
mikroba. Kualitas dan kuantitas bahan organik mempunyai pengaruh langsung terhadap kelimpahan cendawan karena kebanyakan cendawan bersifat heterotrofik (Rao, 1982).

\section{Pengujian Pertumbuhan}

Cendawan pelapuk yang telah dimurnikan diuji kemampuan dan kecepatan tumbuhnya pada tiga jenis media solid. Setiap media padat mengandung komposisi bahan yang berbeda. PDA mengandung ekstrak kentang, pepton pada MPA, dan ekstrak malt pada MEA. Diinkubasi pada suhu ruang dan dilakukan sampai umur 7 hari (Tabel 3).

Semua isolat cendawan pelapuk dapat tumbuh pada tiga jenis media padat tersebut. Secara umum, isolat dapat memenuhi cawan petri mulai hari ke-4 setelah ditumbuhkan. Rata-rata kecepatan pertumbuhan cendawan pelapuk pada hari ke-7 setelah inkubasi yaitu 7-8 cm pada media PDA, 6-7 cm pada media MEA, dan 5-6 cm pada media MPA (Tabel 3).

Walaupun semua isolat ditumbuhkan pada media yang sama, yaitu media agar yang mengandung ekstrak kentang.
Namun menurut Baon et al., (2012) selain dipengaruh genetik, variasi koloni mungkin disebabkan oleh kondisi lingkungan di daerah sampel dan media pertumbuhan, termasuk sumber karbon, $\mathrm{pH}$ dan suhu, dimana sampel diambil pada daerah yang berbeda yaitu pertanaman kelapa sawit dan TKKS di sekitar Pabrik Kelapa Sawit. Perbedaan warna koloni dapat dipengaruhi suhu pada uji laboratorium dan ketersediaan nutrisi pada medium.

Walaupun semua isolat ditumbuhkan pada media yang sama, yaitu media agar yang mengandung ekstrak kentang. Namun menurut Baon et al., (2012) selain dipengaruh genetik, variasi koloni mungkin disebabkan oleh kondisi lingkungan di daerah sampel dan media pertumbuhan, termasuk sumber karbon, pH dan suhu, dimana sampel diambil pada daerah yang berbeda yaitu pertanaman kelapa sawit dan TKKS di sekitar Pabrik Kelapa Sawit. Perbedaan warna koloni dapat dipengaruhi suhu pada uji laboratorium dan ketersediaan nutrisi pada medium. 
Muh. Yusuf Idris : Isolasi dan Karakteristik Jamur Pelapuk dari Batang dan Tandan Kosong Kelapa Sawit

Tabel 2. Karakterisasi morfologi isolat cendawan pelapuk yang diisolasi dari TKKS dan batang kelapa sawit

\begin{tabular}{|c|c|c|c|c|}
\hline \multirow{2}{*}{ Isolat } & \multicolumn{2}{|c|}{ Warna Koloni } & \multirow{2}{*}{ Bentuk } & \multirow{2}{*}{ Tekstur } \\
\hline & Atas & Bawah & & \\
\hline BT1 & "Hijau & Hijau & Bulat kecil-kecil & Agak kasar \\
\hline BT2 & Putih bersih & Putih & Menyebar & Halus \\
\hline BT3 & Putih & Putih & Lingkaran luar tebal & Halus \\
\hline BT4 & Putih & $\begin{array}{l}\text { Putih } \\
\text { kecoklatan }\end{array}$ & $\begin{array}{l}\text { Mengembang seperti kapas } \\
\text { di bagian tengah }\end{array}$ & Agak kasar \\
\hline BT5 & Putih & $\begin{array}{l}\text { Putih } \\
\text { kehijauan }\end{array}$ & $\begin{array}{l}\text { Pinggir lebih tebal } \\
\text { menyebar }\end{array}$ & Halus \\
\hline BT6 & Putih hitam & Hitam & Menyebar tidak merata & Agak Kasar \\
\hline BT7 & Putih coklat & Coklat muda & Menyebar, bulat kompak & Kasar \\
\hline TK8 & Putih kelabu & Keabuan & Menyebar & Agak kasar \\
\hline TK9 & Putih kehijauan & Hijau & Menyebar, tidak merata & Kasar \\
\hline TK10 & Hijau & Hijau & Bulat, tidak merata & Kasar \\
\hline TK11 & Putih & Putih & Bulat, tepi bergerigi & Halus \\
\hline TK12 & Hijau & Hijau & Bulat & Halus \\
\hline TK13 & Putih kehijauan & Hijau & Lonjong, tepi membulat & Halus \\
\hline TK14 & Putih & Putih & Menyebar & Halus kapas \\
\hline TK15 & Putih & $\begin{array}{l}\text { Putih } \\
\text { kecoklatan }\end{array}$ & Bulat & Halus \\
\hline
\end{tabular}

Tabel 3. Rata-rata pertumbuhan koloni $(\mathrm{cm})$ isolat cendawan pelapuk asal TKKS dan batang kelapa sawit pada berbagai media tumbuh

\begin{tabular}{cccc}
\hline & & Jenis Media & \\
\cline { 2 - 4 } Isolat & PDA & MEA & MPA \\
\hline BT1 & 8.45 & 8.60 & 9.00 \\
BT2 & 9.00 & 9.00 & 5.05 \\
BT3 & 8.10 & 6.70 & 5.65 \\
BT4 & 8.25 & 7.35 & 4.15 \\
BT5 & 7.90 & 7.80 & 8.70 \\
BT6 & 6.60 & 9.00 & 8.40 \\
BT7 & 7.55 & 9.00 & 9.00 \\
TK8 & 9.00 & 9.00 & 9.00 \\
TK9 & 9.00 & 9.00 & 9.00 \\
TK10 & 9.00 & 9.00 & 3.25 \\
TK11 & 4.75 & 4.10 & 2.65 \\
TK12 & 6.15 & 3.60 & 1.95 \\
TK13 & 6.60 & 3.15 & 9.00 \\
TK14 & 9.00 & 9.00 & 4.20 \\
TK15 & 5.70 & 5.00 & \\
\hline \hline
\end{tabular}

Keterangan : Potato Dextrose Agar (PDA), Malt Peptone Agar (MPA), dan Malt Extract Agar (MEA). 
Muh. Yusuf Idris : Isolasi dan Karakteristik Jamur Pelapuk dari Batang dan Tandan Kosong Kelapa Sawit
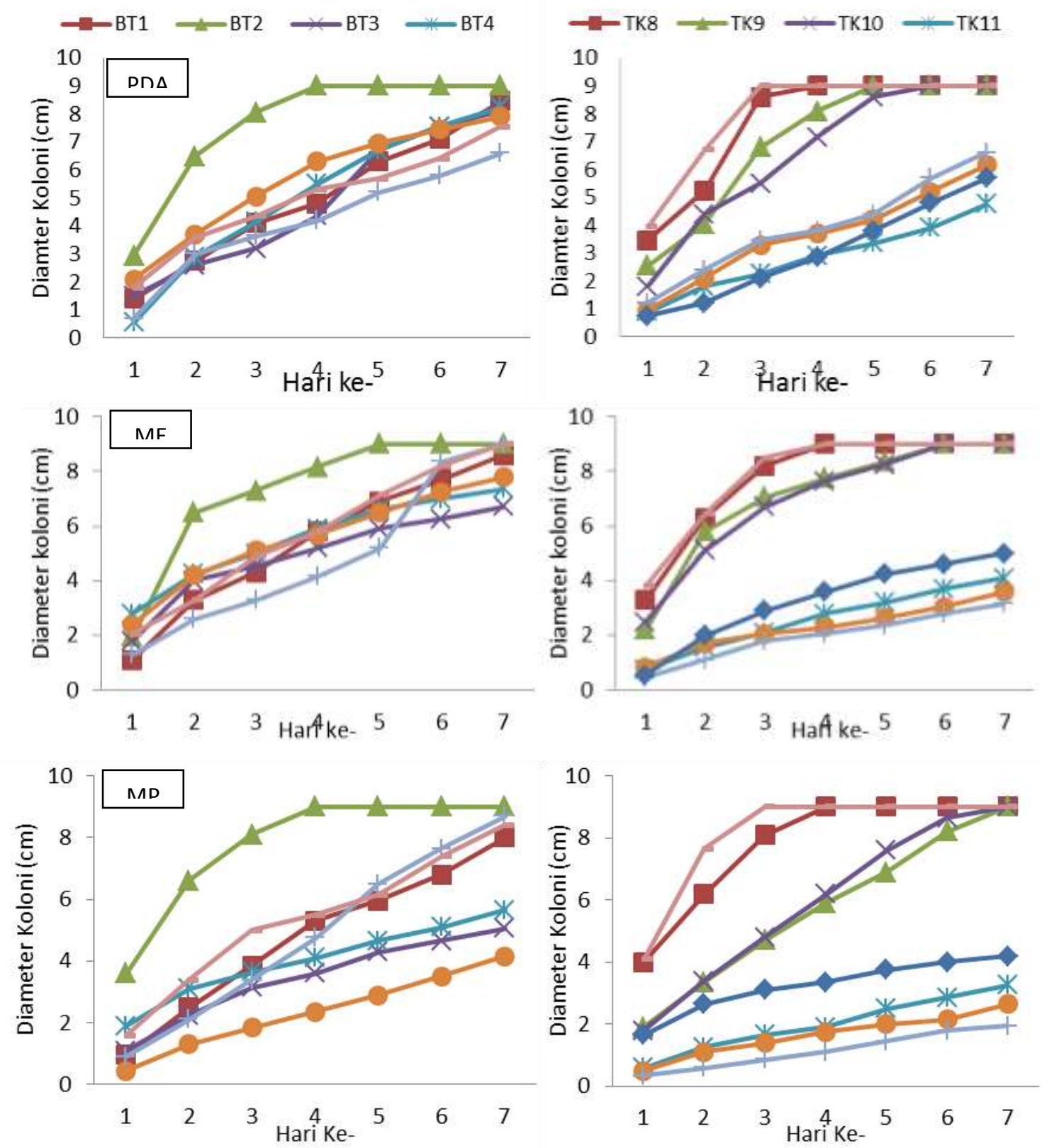

Gambar 2. Laju pertumbuhan isolat cendawan pelapuk pada tiga jenis media (PDA, MEA dan MPA) selama 7 hari inkubasi

Gambar 2 juga menunjukkan pada media PDA isolat TK14 mempunyai diameter koloni tertinggi, dan paling rendah pada isolat TK15. Ada 7 isolat yang tumbuh maksimal pada semua media setelah 7 hari inkubasi, yaitu isolat BT2, nitrogen, karbohidrat, sodium klorida, dan
BT6, BT7, TK8, TK9, TK10 dan TK14. Media PDA memiliki kandungan nutrisi karbohidrat, air, dan protein yang berasal dari substrat kentang, glukosa, dan agaragar. Media MEA memiliki komposisi 
agar-agar, sedangkan media MPA memiliki kandungan nutrisi nitrogen, karbohidrat, sodium klorida, pepton, dan agar-agar. Kandungan karbon pada media mempunyai dua fungsi, yaitu pertama untuk metabolisme bagi organisme heterotropik seperti jamur. Kandungan karbon dalam bentuk unsur $\mathrm{C}$ dibutuhkan untuk proses sintesis dalam kelangsungan hidup sel. Unsur tersebut seperti karbon, asam nukleat, material dinding sel, dan sebagai makanan. Fungsi yang kedua sebagai sumber energi utama yang berasal dari proses oksidasi unsur karbon (Chang and Miles, 1989).

\section{KESIMPULAN}

Hasil isolasi jamur pelapuk berjumlah 32 isolat yang terdiri dari 17 isolat dari batang kelapa sawit yang melapuk dan 15 isolat dari TKKS. Jamur dari batang kelapa sawit yang melapuk yaitu Penicillium sp, Pleurotus sp, Fusarium sp, Chrysosporium sp, Aspergillus sp, dan dari TKKS yaitu Tremella sp, Trichoderma sp, Phytophthora sp, Ulocladium sp, Chaetomium sp dan Absidia sp.

\section{Ucapan Terima Kasih}

Ucapan terima kasih kepada DRPM RISTEK DIKTI yang telah memberikan biaya hibah penelitian pada Program Penelitian Terapan (PPT) Tahun Anggaran 2018.

\section{DAFTAR PUSTAKA}

Athul SR, Jisha MS. 2013. Screening of Trichoderma spp and Pseudomonas spp. for their biocontrol potential against phytopathogens of Vanilla.Int. J. of. Agriculture, Environment \& Biotechnology 6: 799-806.

Bakar, E. S., 2003. Kayu Sawit Sebagai Substitusi Kayu Dari Hutan Alam. Forum Komunikasi dan Teknologi dan Industri Kayu 2 : 5-6. Bogor.

Baon, J.B., S. Wedhastri, A. Kurniawan., 2012. The Ability of Phosphate Solubilizing Bacteria Isolated from Coffee Plant Rhizosphere and Their Effects on Robusta Coffee Seedlings. Journal of Agricultural Science and Technology. 2:1064-1070.

Chang, S.T., P.G. Miles., 1989. Edible mushrooms and their cultivation. Florida: CRC Press, Inc. 451.

Druzhinina IS, Kopchinskiy AG, Kubicek CP. 2006. The first one hundred of Trichoderma species characterized by molecular data.Mycoscience 47: 5564.

Eaton RA, Hale MDC. 1993. Wood, Decay, Pests and Protection. London: Chapman dan Hall.

Gams W, Bissett J. 1998. Morphology and identification of Trichoderma. In Trichoderma and Gliocladium (eds. Kubicek CP and Harman GE). London (USA): Taylor and Francis. 
Hoyos-Carvajal L, Orduz S, Bissett J. 2009. Genetic and metabolic biodiversity of Trichoderma from Colombia and adjacent neotropic regions.J. Fungal Genetics and Biology V 46: 615-631.

Khang VT, Anh NTM, Tu PM, Tham NTH. 2013. Isolation and selection of Trichoderma spp. exhibiting high antifungal activities against major pathogens in Mekong Delta. Omonrice 19: 159-171.

Masai, E., Y. Katayama, and M. Fukuda, 2007. Genetic and biochemical investigations on bacterial catabolic pathways for lignin-derived aromatic compounds. Biosci Biotechnol and Biochemist, 71(1): 1-15.

Rao, N.S., 1982. Biofertilizer in Agriculture. Oxford. Oxford and IBH Publishing Co. New Delhi.

Rifai MA. 1969. A revision of the genus Trichoderma. Mycological Papers 116: 1-56.
Sajab, M.S., C.H. Chia, S. Zakaria, and P.S. Khiew, 2013. Cationic and anionic modifications of oil palm empty fruit bunch fibers for the removal of dyes from aqueous solutions. Bioresource Technology, 128, 571-577.

Sapareng, S., A. Ala, T. Kuswinanti, B. Rasyid, 2017. The Role of Rot Fungi In Composting Process of Empty Fruit Bunches of Oil Palm. Int. J. Curr. Res. Biosci. Plant Biol. 4(3), 17-22.

Shahid M, Srivastava M, Sharma A, Kumar V, Pandey S, Singh A. 2013. Morphological, molecular indentification and SSR marker analysis of a potential strain of Trichoderma/Hypocrea for production of bioformulation.J. Plant Pathol Microb (4)10: 204-211. 